\title{
Programmed Death of T Cells in Human Immunodeficiency Virus Infection No Correlation with Progression to Disease
}

\author{
Linde Meyaard, * Sigrid A. Otto, * Ireneus P. M. Keet, ${ }^{\star}$ Marijke T. L. Roos, ${ }^{*}$ and Frank Miedema * \\ * Department of Clinical Viro-Immunology, Central Laboratory of the Netherlands Red Cross Blood Transfusion Service, Laboratory for \\ Experimental and Clinical Immunology, University of Amsterdam, 1066 CX Amsterdam; and ${ }^{\ddagger}$ Department of Public Health and \\ Environment, Municipal Health Service, 1018 WT Amsterdam, The Netherlands
}

\begin{abstract}
Programmed death of $T$ cells has been proposed as one of the mechanisms by which HIV affects immune functions in stages of infection where the number of infected cells is low. Indeed, in HIV-infected individuals both $\mathrm{CD4}^{+}$and $\mathrm{CD8}^{+} \mathrm{T}$ cells are primed for programmed cell death, which can be enhanced by polyclonal stimulation. Here, we investigated programmed death of $T$ cells in all stages of HIV infection, including acute infection. In individuals with primary infection the number of $T$ cells dying due to apoptosis was much higher than in the asymptomatic phase of infection and paralleled increased numbers of $\mathrm{CD8}^{+}$cells. In asymptomatic HIV-infected individuals, cells were dying in increased percentages compared with noninfected controls, although at much lower numbers than during acute infection. Death of $T$ cells was not quantitatively correlated with $\mathrm{CD4}^{+} \mathrm{T}$ cell numbers or appearance of more cytopathic, syncytium-inducing HIV variants. Analysis of the phenotype of cells undergoing apoptosis revealed that cell death was not confined to a specific $T$ cell subset nor correlated with expression of certain $\mathrm{T}$ cell activation markers. Our results imply that the extent of programmed cell death of $T$ cells in HIV infection does not correlate with progression to disease. (J. Clin. Invest. 1994. 93:982-988.) Key words: human immunodeficiency virus infection • apoptosis $\bullet T$ cells $\bullet$ immunopathology $\bullet T$ cell function
\end{abstract}

\section{Introduction}

In the asymptomatic phase of HIV infection, immunological abnormalities can be demonstrated already before $\mathrm{CD}^{+} \mathrm{T}$ cell numbers start to decline. Both $\mathrm{CD}^{+}{ }^{+}$and $\mathrm{CD}^{+} \mathrm{T}$ cell functions, such as IL- 2 production and proliferation after stimulation with recall antigens and CD3 antibodies, are affected (15 ). The mechanism by which HIV is capable of affecting immune function in a stage of infection where the number of infected cells is low $(6,7)$ remains to be elucidated.

It has been proposed that T cells in HIV-infected individuals are programmed for death and that upon activation they will die due to apoptosis (8). Indeed, recent results from our

Address correspondence to Dr. Frank Miedema, Central Laboratory of the Netherlands Red Cross Transfusion Service, Department of Clinical Viro-Immunology, Pleasmanlaan 125, 1066 CX Amsterdam, The Netherlands.

Received for publication 31 August 1993 and in revised form 2 November 1993.

J. Clin. Invest.

(C) The American Society for Clinical Investigation, Inc. 0021-9738/94/03/0982/07 \$2.00

Volume 93, March 1994, 982-988 group and others (9-11) demonstrated cell death by apoptosis of PBMC of HIV-infected individuals in vitro. Programmed cell death $(\mathrm{PCD})^{1}$ occurred in both $\mathrm{CD}^{+}{ }^{+}$and $\mathrm{CD}^{+} \mathrm{T}$ cells and was enhanced by activation in vitro $(9,11)$.

In HIV-infected chimpanzees that do not develop clinical symptoms, the proportion of T cells dying due to PCD does not exceed that in noninfected animals $(11,12)$. This could imply either a function for PCD in HIV pathogenesis in humans, or that PCD is a reflection of immunopathogenic events.

It has been suggested that interaction of soluble gp 120 with CD4 could prime T cells for PCD (8). Cross-linking of bound gp 120 on human $\mathrm{CD} 4^{+} \mathrm{T}$ cells followed by signaling through the TCR results in apoptosis in vitro (13). This, however, can not explain death of $\mathrm{CD}^{+} \mathrm{T}$ cells $(9,11) \cdot \mathrm{CD}^{+} \mathrm{T}$ cells from HIV-infected individuals have increased expression of activation markers, such as CD38, HLA-DR, and CD57, suggesting continuous immune activation $(14,15) . \mathrm{CD}^{+}$cells expressing activation markers have severely decreased proliferative responses and clonogenic potential (16) and are reported to die in culture (17).

PCD of $T$ cells has been described in acute lymphocytic choriomeningitis virus ( LCMV) infection in mice (18), correlating with hyporesponsiveness as a result of hyperactivation of $T$ cells in vivo. Similar findings have been reported for EpsteinBarr virus infection in humans $(19,20)$, where both $\mathrm{CD}^{+}$and $\mathrm{CD}^{+}$cells die upon culture. Dying cells were confined to the $\mathrm{CD} 45 \mathrm{RO}^{+}$population and cell death could be prevented by culture in the presence of cytokines like IL-2 (20). Also in that condition, PCD was suggested to affect the population of activated $T$ cells that expands during the acute phase of the infection.

We investigated the occurrence of PCD in sequential stages of HIV infection. PCD was studied in primary infection and in the asymptomatic phase of infection in relation to $\mathrm{CD}^{+}{ }^{+}$and $\mathrm{CD}^{+} \mathrm{T}$ cell counts. Moreover, PCD was studied in longitudinal samples from individuals followed from seroconversion until AIDS. Finally, the phenotype of cells undergoing PCD and the influence of the addition of growth factors in vitro were studied.

\section{Methods}

$m A b s$. The mAbs CLB-T3/4.E (CD3) (21) and CLB-CD19 (CD19) were produced at the Central Laboratory of the Netherlands Red Cross Blood Transfusion Service (Amsterdam, The Netherlands). UCHL1 (CD45RO) was a generous gift of Dr. P. Beverly (University College, London, UK) and UCHL1-FITC was purchased from Dakopatts (Glostrup, Denmark). 2H4, 2H4-FITC, and 2H4-phycoerythrin (PE) (CD45RA) mAbs were purchased from Coulter Immunology (Hia-

1. Abbreviations used in this paper: NSI, non-syncytium-inducing; PCD, programmed cell death; SI, syncytium-inducing. 
leah, FL), and labeled antibodies against CD38, HLA-DR, and CD57 (Leu-17-PE, HLA-DR-PE, and Leu-7-FITC) from Becton Dickinson \& Co. (Sunnyvale, CA).

Subjects. Three male and one female were studied early after virus transmission. Samples were taken frequently around the time of seroconversion and at longer intervals in the weeks thereafter. All four individuals presented clinical symptoms of acute infection as described (22). For studies on the asymptomatic phase of HIV infection, participants of the Amsterdam cohort study on HIV infection in homosexual men (23) were studied transsectionally by analyzing freshly isolated cells and retrospectively by use of cryopreserved cells.

Cells. PBMC were isolated by Ficoll-Paque density gradient centrifugation from heparinized blood and directly used or cryopreserved as indicated. Viable cells were preserved in liquid nitrogen and cryopreservation did not markedly influence the percentages of cells in apoptosis. For some experiments cells were purified by either cell separation or sorting techniques.

Cells $\left(10^{6}\right)$ were then cultured in $1 \mathrm{ml}$ Iscove's modification of Dulbecco's medium (IMDM) supplemented with 10\% FCS (in the absence or presence of CD3 mAb CLB-T3/4.E [21]). In experiments indicated, growth factors were added in culture, and after overnight culture, cells were harvested and DNA fragmentation was examined by gel electrophoresis or in situ nick translation.

The following $\mathrm{T}$ cell growth factors were used: $50 \mathrm{U} / \mathrm{ml} \mathrm{rIL-2}$ and/ or $5 \mathrm{ng} / \mathrm{ml} \mathrm{rIL-1} \alpha$ (both obtained from Hoffman-La Roche, Nutley, $\mathrm{NJ}$ ) or $10 \%$ of the enriched supernatant of Con A-activated healthy donor PBMC. To generate this supernatant, pooled PBMC from 10 healthy donors were cultured in IMDM containing $10 \%$ FCS and 1 $\mathrm{ng} / \mathrm{ml}$ PMA. After $24 \mathrm{~h} 5 \mathrm{mg} / \mathrm{ml}$ Con A was added and $48 \mathrm{~h}$ thereafter the supernatant was harvested and showed to contain $680 \mathrm{U} / \mathrm{ml} \mathrm{IL-2}$ and $60 \mathrm{ng} / \mathrm{ml}$ IFN- $\gamma$.

Cell separation and sorting. PBMC were depleted for either B cells $\left(\mathrm{CD} 9^{+}\right)$and naive $\mathrm{T}$ cells $\left(\mathrm{CD} 45 \mathrm{RA}^{+}\right)$or B cells and memory $\mathrm{T}$ cells $\left(\mathrm{CD}_{45 \mathrm{RO}^{+}}\right.$) by CD19 (CLB-CD19) and CD45RA (2H4) or CD45RO (UCHL-1) mAbs and anti-mouse IgG-coated magnetic beads as de-

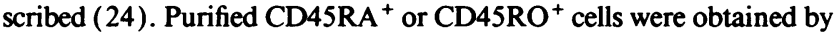
staining PBMC with 2H4-PE and UCHL1-FITC and subsequent cell sorting on a FACStar ${ }^{\circledR}$ (Becton Dickinson Co.).

DNA extraction and electrophoresis. DNA fragmentation was visualized by a modification of the method of Sellins and Cohen (25). Cells were lysed with $0.5 \mathrm{ml}$ hypotonic lysis buffer ( $10 \mathrm{mM}$ Tris, $1 \mathrm{mM}$ EDTA, $0.2 \%$ Triton X-100). The lysates were immediately centrifuged at $13,000 \mathrm{~g}$ for $10 \mathrm{~min}$ and the supernatant, containing fragmented DNA, was collected. Proteins were removed by phenol-chloroform-isoamylalcohol extraction and DNA was precipitated overnight with a 1:20 vol $3 \mathrm{M} \mathrm{NaAc}$ and 2 vol $96 \%$ ethanol at $-20^{\circ} \mathrm{C}$. Pellets were washed with $70 \%$ ethanol, air dried, and dissolved in $12 \mu \mathrm{l}$ RNase A (final concentration, $20 \mu \mathrm{g} / \mathrm{ml}$ ) in $10 \mathrm{mM}$ Tris, $1 \mathrm{mM}$ EDTA, pH 7.4, and incubated for $30 \mathrm{~min}$ at $37^{\circ} \mathrm{C}$. After addition of $3 \mu$ loading buffer ( $50 \mathrm{mM}$ EDTA, pH 8.0, 15\% [wt/ vol] Ficoll, 0.25\% [wt/vol] bromophenol blue), samples were heated at $65^{\circ} \mathrm{C}$ for $15 \mathrm{~min}$ and electrophoresis was performed in $1.5 \%$ agarose for $1.5 \mathrm{~h}$ at $60 \mathrm{~V}$. DNA was visualized by staining with ethidium bromide under UV light.

Quantitative analysis of DNA fragmentation by in situ nick translation. Percentages of cells containing fragmented DNA were determined by in situ nick translation (9). Cells $\left(0.5-2 \times 10^{6}\right)$ were fixed in $1 \%$ formaldehyde and $70 \%$ ethanol sequentially. After washing, cells were incubated $\left(90 \mathrm{~min}, 15^{\circ} \mathrm{C}\right)$ in a total volume of $10 \mu \mathrm{l}$, with $30 \mu \mathrm{M}$ biotin-labeled dUTP (biotin-16-dUTP; Boehringer Mannheim, Mannheim, Germany), a mixture of $26 \mu \mathrm{M}$ dATP, dGTP, and dCTP (Boehringer, Mannheim), and DNA polymerase $(100 \mathrm{U} / \mathrm{ml})$ in $50 \mathrm{mM}$ Tris$\mathrm{Cl}, \mathrm{pH}$ 7.8, $5 \mathrm{mM} \mathrm{MgCl}$, $0.1 \mathrm{M}$ 2-mercaptoethanol and bovine serum albumin $(10 \mu \mathrm{g} / \mathrm{ml}$ ). Cells were washed in PBS containing $0.1 \%$ (vol/ vol) Triton X-100 and incubated with $40 \mu$ FITC-labeled avidin (DCS grade; Vector Laboratories, Burlingame, CA $)(2.5 \mu \mathrm{g} / \mathrm{ml})$ and RNase $(20 \mu \mathrm{g} / \mathrm{ml})$ in $4 \times$ SSC, $0.1 \%$ ( vol/vol) Triton X-100, and $5 \%(\mathrm{wt} / \mathrm{vol})$ nonfat dry milk for $30 \mathrm{~min}$ at room temperature. Cells were then washed and resuspended in PBS containing $0.1 \%$ (vol/vol) Triton
$\mathrm{X}-100$ and propidium iodide $(5 \mu \mathrm{g} / \mathrm{ml})$ and analyzed on a FACScan ${ }^{\otimes}$ cytofluometer. The percentage of FITC-positive cells within the cells in $\mathrm{G}_{0} / \mathrm{G}_{1}$ phase as determined by the propidium iodide staining represents the percentage of cells in apoptosis.

In experiments in which the cells were counterstained with PE-labeled $\mathrm{mAb}$ directed against CD45RA, CD45RO, CD38, or HLA-DR, cells were fixed in $2 \%$ paraformaldehyde $\left(10 \mathrm{~min}, 0^{\circ} \mathrm{C}\right)$, washed in PBS containing $5 \%$ pooled human serum and $1 \% \mathrm{BSA}$, and incubated for 10 min at $0^{\circ} \mathrm{C}$ in $0.01 \% \mathrm{NP}-40$. The in situ nick translation was then performed as described above, thereby using $0.02 \%$ (vol/vol) Tween20 in $20 \times$ SSC for washings. After incubation with avidin-FITC, cells were washed with PBS supplemented with $0.5 \%$ BSA. Cells were then incubated $30 \mathrm{~min}$ at $4^{\circ} \mathrm{C}$ with PE-labeled $\mathrm{mAb}$ and washed twice before analysis on a FACScan ${ }^{\oplus}$. Reproducible analysis with CD8-PE was not possible, since apoptotic cells lose expression of CD8 (data not shown).

\section{Results}

$P C D$ increases in parallel with $C D 8^{+}$cell numbers in primary $H I V$ infection. In primary HIV infection often a transient $\mathrm{CD}^{+}{ }^{+}$lymphocytosis is observed, during which a high proportion of $\mathrm{CD}^{+}$cells expresses activation markers as CD38 and HLA-DR (22). Here, PCD was analyzed after overnight culture in samples obtained from four individuals early after HIV transmission. In Fig. 1, percentages of cells undergoing apoptosis as well as absolute $\mathrm{CD} 4^{+}$and $\mathrm{CD} 8^{+} \mathrm{T}$ cell numbers are shown. The individual presented in Fig. $1 A$ had an increase in $\mathrm{CD}^{+}$cell numbers that peaked around day 9 after seroconversion, associated with a high percentage of cells in apoptosis (up to $58 \%$ ). In the period thereafter the number of cells dying due to PCD was in range with numbers of cells in PCD in asymptomatic HIV-infected individuals (9). The DNA fragmentation pattern typical for PCD as observed 4 and $9 \mathrm{~d}$ after seroconversion is shown (Fig. $1 A$, inset).

The patient described in Fig. $1 B$ did not display a marked increase in $\mathrm{CD}^{+}$cell numbers, and in concordance the percentages of cells undergoing PCD, although above background values, were not exceedingly high. Fig. $1 C$ shows an individual in which $\mathrm{CD}^{+}$cell numbers were increased for a prolonged period of time. The high number of cells undergoing PCD had returned to levels normally observed in HIV-infected individuals only $78 \mathrm{~d}$ after seroconversion. Finally, the high proportion of cells in apoptosis in the fourth patient was accompanied by increased but not extremely high $\mathrm{CD} 8{ }^{+} \mathrm{T}$ cell numbers (Fig. $1 D$ ). In none of these patients was a correlation between the levels of p24 antigen in plasma or virus load in PBMC and the amount of cells in apoptosis observed (Koot, M., A. B. van't Wout, N. A. Kootstra, R. E. Y. de Goede, R. A. Coutinho, M. Tersmette, and $\mathrm{H}$. Schuitemaker, manuscript in preparation). Thus, in acute HIV infection PCD mainly seems to be related to the expansion of $\mathrm{CD}^{+}$cells.

$P C D$ of $T$ cells in asymptomatic HIV infection is not correlated with stage of infection. During the asymptomatic stage of HIV infection, several changes in immunological and virological parameters can be observed. Associated with rapid progression to AIDS are rapid loss of $\mathrm{CD}^{+} \mathrm{T}$ cell numbers and loss of $T$ cell function, as measured by proliferation in response to CD3 antibodies as well as the emergence of syncytium-inducing (SI) HIV variants $(5,26)$. A group of 52 asymptomatic HIV-infected men were stratified for absolute $\mathrm{CD} 4^{+}$and $\mathrm{CD} 8^{+}$ $T$ cell numbers. As shown in Fig. $2 A$, the range of cells undergoing apoptosis was comparable in all groups, regardless of 

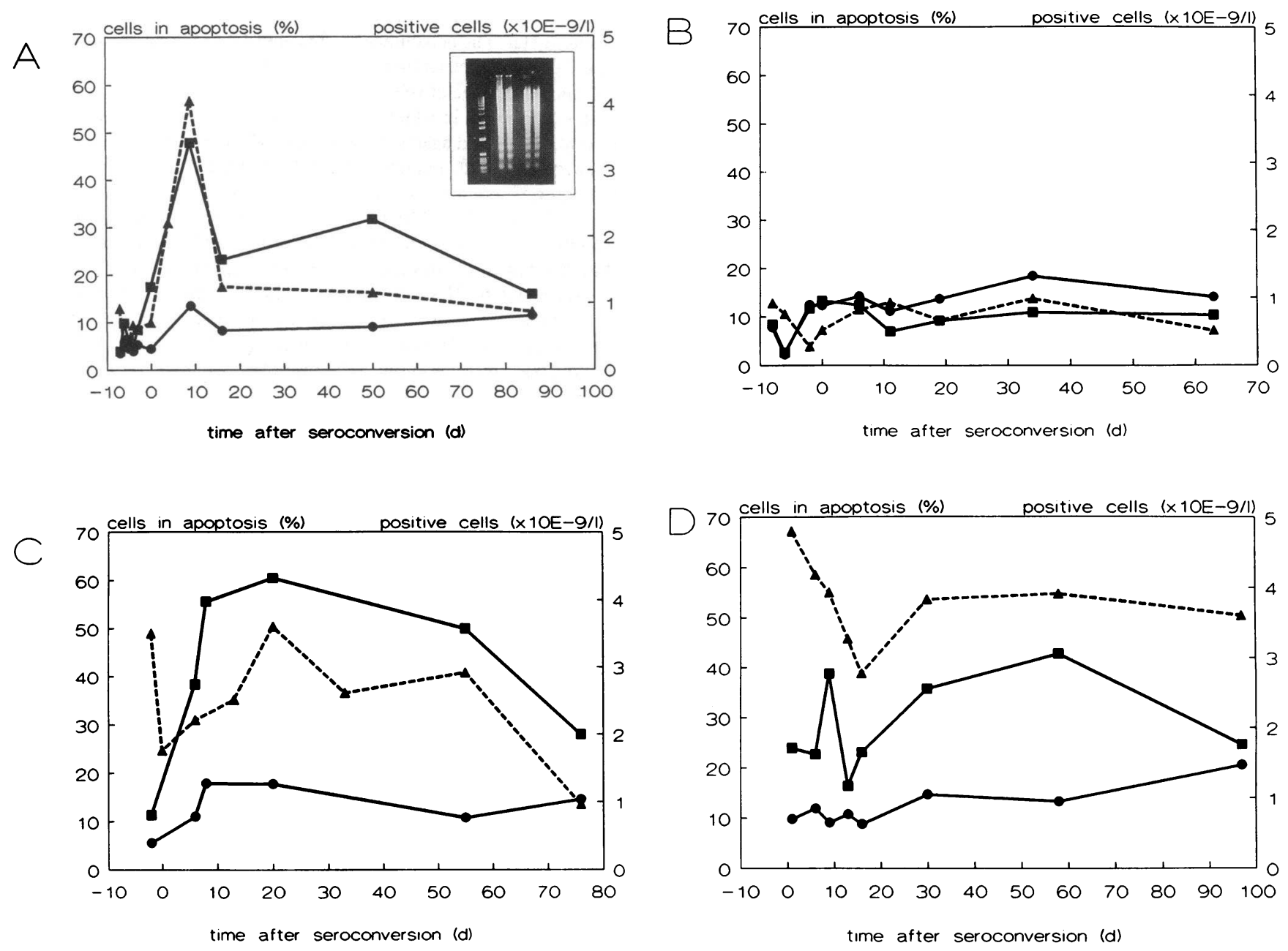

Figure 1. PCD in primary HIV infection from four different individuals $(A-D)$ followed shortly after virus transmission. Percentages of cells undergoing apoptosis after overnight culture of PBMC in the absence of any stimulus $(\triangle)$ as well as absolute CD4 $4^{+} \mathrm{T}$ cells numbers $(\bullet)$ and $\mathrm{CD}^{+} \mathrm{T}$ cell numbers $(a)$ are shown. For the individual in $A$, the DNA fragmentation pattern typical for PCD as observed at 4 and $9 \mathrm{~d}$ after seroconversion is shown. (Inset) From left to right are shown a molecular weight marker, day 4 in duplicate, and day 9 in duplicate.

$\mathrm{CD} 4^{+} \mathrm{T}$ cell counts. A relation between PCD and decline in $\mathrm{CD}^{+}{ }^{+}$cells was not found either (data not shown).

Analysis of PBMC from four patients, sampled longitudinally during all stages of HIV infection from seroconversion to AIDS, showed no change in percentages of apoptotic cells over time (Fig. 3). As demonstrated by the samples taken before seroconversion, which were available from two individuals, apoptosis increased after HIV infection but varied over time. Percentage apoptotic cells appeared not to be related to virus load, as determined by clonal virus isolation in these individuals (Koot, M., A. B. van't Wout, N. A. Kootstra, R. E. Y. de Goede, R. A. Coutinho, M. Tersmette, and H. Schuitemaker, manuscript in preparation). Phenotyping of the HIV variants isolated from these individuals demonstrated that all four had gone through a transition from non-syncytium-inducing (NSI) variants to SI variants during infection, which is known to correlate with an increased $\mathrm{CD}^{+} \mathrm{T}$ cell decline and progression to AIDS (26). The number of apoptotic $T$ cells in these four patients was not altered by the appearance of SI viruses, compatible with additional data on PCD in five individuals 6 and 3 mo before and 3 and 6 mo after NSI to SI conversion (data not shown).
In acute infection high percentages of PCD were related to high $\mathrm{CD}^{+}$cell counts. In agreement, in the asymptomatic phase of infection both $\mathrm{PCD}$ and $\mathrm{CD}^{+}$cell counts are decreased. In the asymptomatic phase $\mathrm{CD} 8^{+} \mathrm{T}$ cell numbers are steadily increasing over time. Since an association of high percentages of cells dying from PCD with increased numbers of $\mathrm{CD}^{+}$cells was observed in primary infection, we analyzed this relation in the asymptomatic group. In this relatively small range of $\mathrm{CD}^{+}$cell counts no correlation with $\mathrm{PCD}$ was found (Fig. 2 B).

Phenotype of cells undergoing PCD. HIV-infected individuals have increased numbers of $\mathrm{CD}^{+} \mathrm{T}$ cells expressing activation markers CD38, HLA-DR, and CD57 $(14,15)$. These cells have severely decreased proliferative responses and clonogenic potential (16) and have been reported to die in culture (17). In addition, PCD of $T$ cells during acute Epstein-Barr virus infection was reported to occur exclusively in $\mathrm{CD}^{-} 5 \mathrm{RO}^{+}$populations (20).

To investigate the phenotype of apoptotic cells in HIV-infected individuals we took four different approaches. First, we investigated the phenotype of $T$ cells from an asymptomatic HIV-infected individual directly after isolation and after $2 \mathrm{~d}$ of 
A

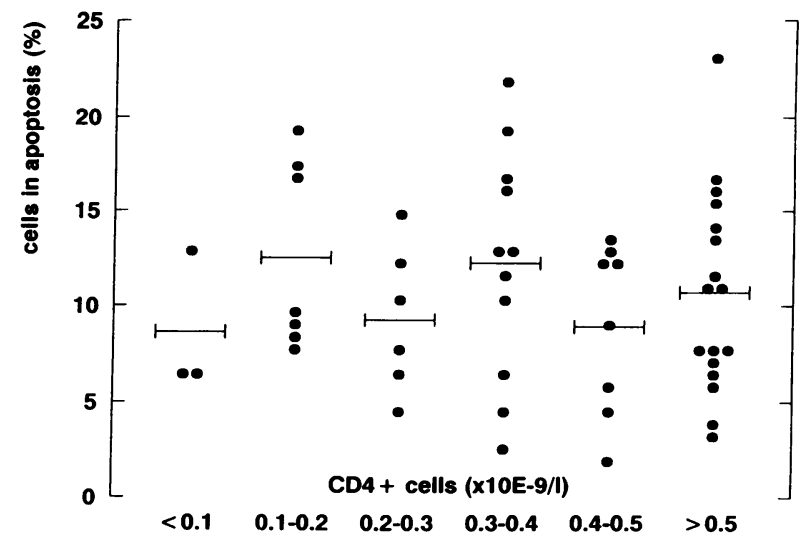

B

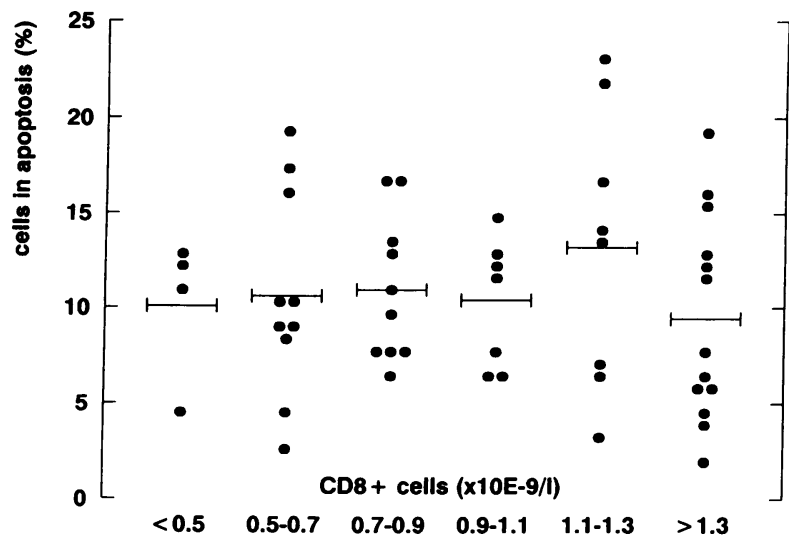

Figure 2. $\mathrm{PCD}$ related to $\mathrm{CD} 4^{+}$or $\mathrm{CD}^{+} \mathrm{T}$ cell counts in the asymptomatic phase of infection. Percentages of cell death after overnight culture of PBMC from 52 asymptomatic HIV-infected individuals, grouped according to their absolute $\mathrm{CD}^{+}(A)$ or $\mathrm{CD}^{+}(B) \mathrm{T}$ cell numbers. Each dot represents one individual; bars represent means.

culture. Despite the fact that a large proportion of the cells died in culture, the phenotype of remaining $T$ cells was comparable to the freshly isolated cells, compatible with random cell death (Table I). Second, PBMC from an asymptomatic HIV-infected individual and an HIV-negative control were depleted for either $\mathrm{CD}^{4} 5 \mathrm{RA}^{+}$or $\mathrm{CD}^{-} 5 \mathrm{RO}^{+}$cells by using $\mathrm{mAb}$ and anti-mouse IgG-coated magnetic beads, and cultured in the absence or presence of $\mathrm{CD} 3 \mathrm{mAb}$. After overnight culture, DNA fragmentation evidenced by gel electrophoresis was observed in both $\mathrm{T}$ cell subsets (Fig. $4 \mathrm{~A}$ ).

Third, PBMC from an asymptomatic HIV-infected individual were stained with CD45RA-PE and CD45RO-FITC, sorted on a FACStar ${ }^{\circledR}$, and placed into culture in the absence or presence of CD3 mAb. After overnight culture, both populations died to the same extent, as determined by in situ nick translation (Fig. $4 \mathrm{~B}$ ). From these experiments it might be concluded that in PBMC from asymptomatically HIV-infected individuals the percentage of CD45RA ${ }^{+}$and $C D 45 \mathrm{RO}^{+}$cells dying from PCD is comparable.

Finally, we analyzed the phenotype of apoptotic cells from individuals both during primary and asymptomatic HIV infection. Analysis of the number of cells undergoing apoptosis as described in the previous experiments was performed by in situ nick translation. In this assay, apoptotic cells are visualized on a FACScan ${ }^{\circledast}$ by incorporation of FITC-labeled nucleotides in

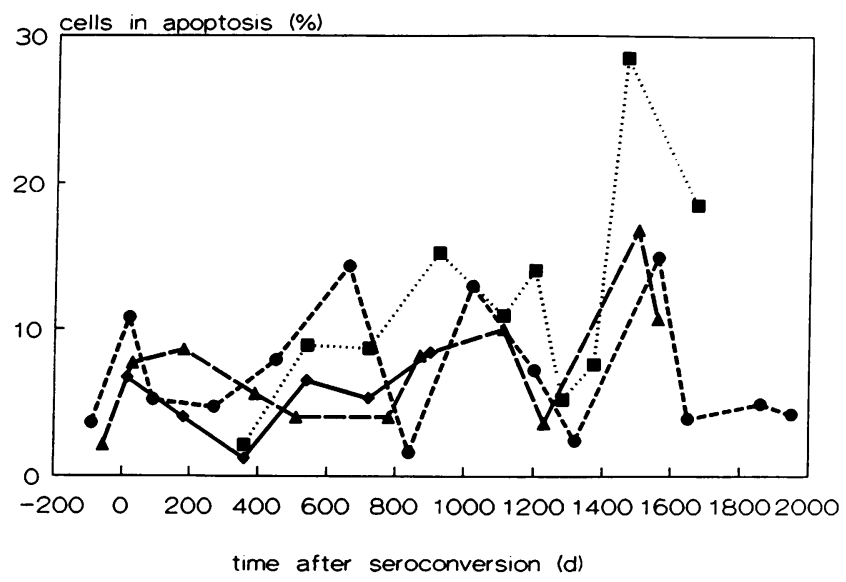

Figure 3. Longitudinal study of PCD in all stages of infection in four individuals. Percentages of cell death after overnight culture of PBMC from four individuals ( $\triangle, A ; \bullet, B ; \bullet, C ; \bullet, D)$. Cryopreserved PBMC collected every 3 mo were thawed and placed into culture. Percentages of cell death were determined in one experiment for each individual. SI variants emerged on day 780 (A), 870 (B), 1,560 (C), and 1,463 (D) after seroconversion, respectively, while these individuals were diagnosed with AIDS at day 1,560 (A), 870 (B), and 1,950 (C) after seroconversion. Individual $\mathrm{D}$ remained asymptomatic during the period studied.

cells containing DNA strand breaks. Double staining with PElabeled $\mathrm{mAb}$ directed against membrane markers allows for quantification of apoptotic cells and phenotyping at the same time. PBMC from HIV-infected individuals were cultured overnight, and the percentage of cells expressing CD4, CD45RA, CD45RO, CD38, and HLA-DR within the apoptotic and nonapoptotic cells was determined. In three out of four patients, the percentage of $\mathrm{CD}^{+}$cells was lower in the apoptotic cell fraction, in agreement with our previous observations

Table I. Lymphocyte Subpopulations from an Asymptomatic $H I V$-infected Individual before and after Culture

\begin{tabular}{|c|c|c|}
\hline & \multicolumn{2}{|c|}{ Days after start culture } \\
\hline & 0 & 2 \\
\hline $\mathrm{CD}^{+}$ & $87.7^{*}$ & 85.3 \\
\hline $\mathrm{CD}^{+}$ & 43.3 & 46.9 \\
\hline $\mathrm{CD}^{+}$ & 52.2 & 45.0 \\
\hline $\mathrm{CD} 45 \mathrm{RA}^{+}$in $\mathrm{CD}^{+}$ & 68.6 & 59.0 \\
\hline in $\mathrm{CD}^{+}$ & 62.5 & 63.6 \\
\hline $\mathrm{CD} 45 \mathrm{RO}^{+}$in $\mathrm{CD}^{+}$ & 33.4 & 42.4 \\
\hline in $\mathrm{CD}^{+}$ & 40.0 & 44.0 \\
\hline $\mathrm{CD}_{38^{+}}$in $\mathrm{CD}^{+}$ & 81.4 & 75.0 \\
\hline in $\mathrm{CD}^{+}$ & 95.7 & 96.4 \\
\hline $\mathrm{CD} 7^{+}$in $\mathrm{CD}^{+}$ & 10.2 & 17.1 \\
\hline in $\mathrm{CD}^{+}$ & 48.0 & 48.2 \\
\hline $\mathrm{HLA}^{-\mathrm{DR}^{+}}$in $\mathrm{CD}^{+}$ & 20.2 & 16.6 \\
\hline in $\mathrm{CD}^{+}$ & 58.1 & 44.7 \\
\hline
\end{tabular}

PBMC from an HIV-infected individual were phenotypically analyzed with $\mathrm{mAb}$ and $\mathrm{FACScan}{ }^{\otimes}$ either directly after isolation or after $2 \mathrm{~d}$ of culture.

* Percent positive cells. 

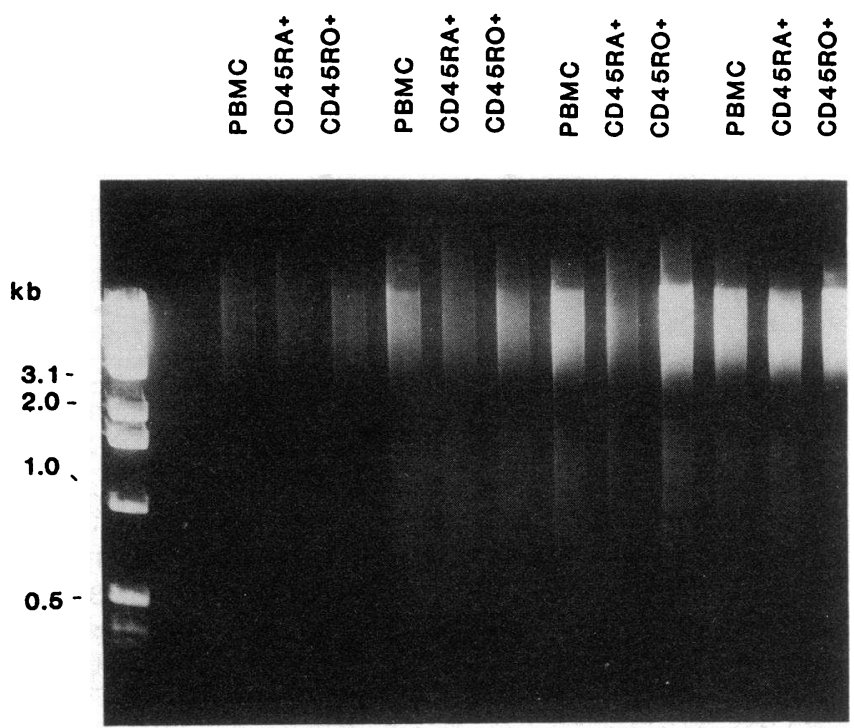

stimulus

anti-CD3

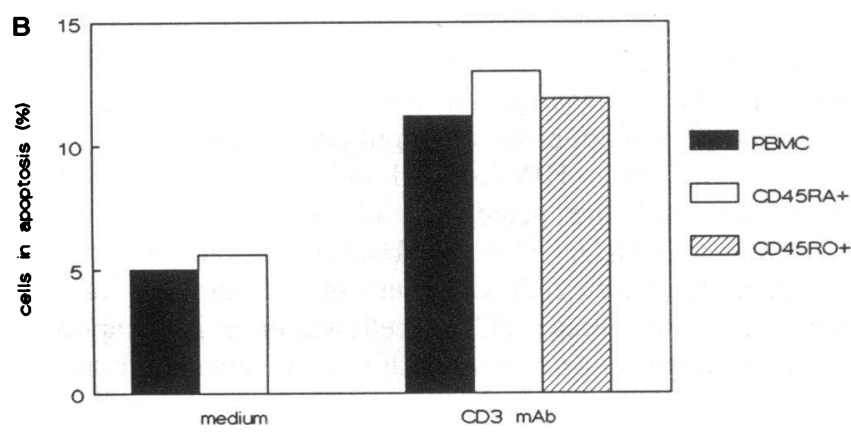

Figure 4. PCD of both $\mathrm{CD} 45 \mathrm{RA}^{+}$and $\mathrm{CD} 45 \mathrm{RO}^{+} \mathrm{T}$ cells in asymptomatic HIV infection. $(A)$ PBMC from an asymptomatic HIV-infected individual and an HIV-negative control were depleted for ei-

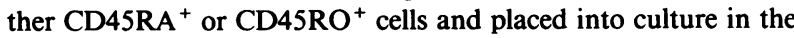
absence or presence of CD3 mAb. After overnight culture, DNA fragmentation was observed in both populations by gel electrophoresis. ( $B$ ) PBMC from an asymptomatic HIV-infected individual were stained with CD45RA-PE and CD45RO-FITC mAbs, sorted by FACStar ${ }^{\circledR}$, and placed into culture in the absence or presence of CD3 $\mathrm{mAb}$. After overnight culture apoptosis was determined by in situ nick translation.

(9). Although the percentage of cells expressing HLA-DR was somewhat higher in the apoptotic cell fraction in three out of four patients, overall the markers studied did not point to a selective death of certain T cell subpopulations ( Table II).

$T$ cell growth factors cannot prevent $P C D$ of $T$ cells in vitro. Massive immune activation leading to exhaustion of growth and survival factors might be the cause of the observed PCD in PBMC of HIV-infected individuals. The addition of growth factors in vitro might rescue cells from programmed cell death. We cultured cells from asymptomatic HIV-infected individuals in the absence or presence of CD3 antibodies. Percentages of cell death were $5.4-11.7 \%$ in unstimulated cultures and
Table II. Phenotype of Apoptotic Cells in Asymptomatic and Primary HIV-infected Individuals

\begin{tabular}{lcccccc}
\hline \multicolumn{1}{c}{ Patient } & $\begin{array}{c}\text { Cells in } \\
\text { apoptosis }\end{array}$ & CD4 & CD45RA & CD45RO & CD38 & HLA-DR \\
\hline & $\%$ & & & & & \\
A (day 9) & $56.7^{\ddagger}$ & & & & & \\
Apoptosis + & & & & & $52.7^{\S}$ & 46.5 \\
Apoptosis - & & & & & 38.9 & 30.6 \\
A (day 86) & 12.1 & & & & & \\
Apoptosis + & & 20.8 & & & 22.0 & \\
Apoptosis - & & 40.4 & & & 29.1 & \\
D (day 9) & 55.1 & & & & & \\
Apoptosis + & & 9.4 & 22.1 & 79.8 & 90.1 & 74.6 \\
Apoptosis - & & 19.4 & 44.6 & 79.2 & 80.1 & 65.0 \\
RV & 18.7 & & & & & \\
Apoptosis + & & 43.6 & 59.4 & & & 36.6 \\
Apoptosis - & & 35.6 & 46.9 & & & 65.1 \\
207 & 6.8 & & & & & \\
Apoptosis + & & 9.3 & 58.8 & 44.2 & 32.1 & 82.0 \\
Apoptosis - & & 17.9 & 59.1 & 34.1 & 40.6 & 59.6 \\
\hline
\end{tabular}

After overnight culture apoptotic cells were visualized by in situ nick translation and phenotyped by double staining with PE-labeled antibodies.

* From $\mathrm{A}$ and $\mathrm{D}$ samples were analyzed during acute HIV infection (see Fig. 1, $A$ and $D$, days after seroconversion are indicated). RV and 207 are asymptomatic HIV-infected individuals. ${ }^{\ddagger}$ Percent cells in apoptosis in PBMC as determined by in situ nick translation.

${ }^{\S}$ Percent positive cells for membrane marker indicated in either apoptotic or nonapoptotic cells.

$15.2-25.4 \%$ in cultures where CD3 mAbs were added. Various growth factors were added to parallel cultures: recombinant IL-2 and/or IL- $1 \alpha$ or supernatant of Con A-activated healthy donor PBMC. None of these growth factors markedly increased cell survival (Fig. 5).

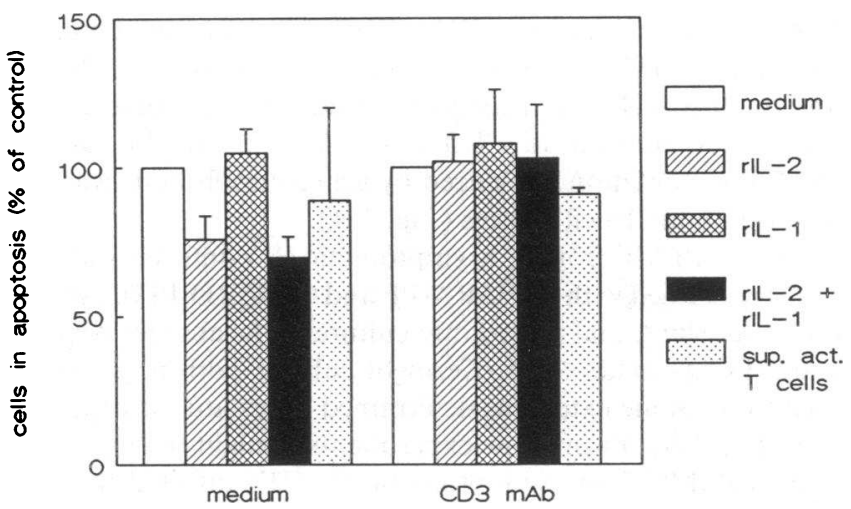

Figure 5. Addition of growth factors in vitro does not prevent PCD of $T$ cells. PBMC of asymptomatic individuals were cultured overnight in the absence or presence of CD3 mAb in medium containing various growth factors: recombinant IL-2 and/or IL- $1 \alpha$ or supernatant of Con A-activated healthy donor PBMC (sup. act. T cells). Data are expressed as percentage of control (without additional growth factors). Bars represent mean of three donors analyzed in three independent experiments \pm standard deviation. 


\section{Discussion}

Here we demonstrate that in primary HIV infection the percentage of $\mathrm{T}$ cells dying due to apoptosis parallels increased numbers of $\mathrm{CD}^{+}$cells. In one of the individuals studied no dramatic increase in $\mathrm{CD} 8^{+}$cells was observed and the percentage of $T$ cells undergoing PCD did not exceed the levels normally observed in asymptomatic HIV-infected individuals. $P C D$ as a result of massive immune activation after acute virus infection is not specific for HIV infection since it was also demonstrated for primary $\operatorname{EBV}(19,20)$ and cytomegalovirus ( Van den Berg, A. P., L. Meyaard, L. H. F. M. de Ley, S. A. Otto, G. Mesander, W. J. van Son, I. J. Klompmaker, F. Miedema, and T. H. The, manuscript submitted for publication ) infection in humans and LCMV infection in mice (18), where a correlation with $\mathrm{T}$ cell hyporesponsiveness and PCD was demonstrated.

As the percentage of $\mathrm{CD}^{+} \mathrm{T}$ cells expressing activation markers, including CD38, CD57 and HLA-DR, in primary infection is high, one might speculate that a large proportion of dying cells can be accounted for by turnover of hyperactivated $\mathrm{CD}^{+} \mathrm{T}$ cells. This would be in agreement with the earlier reported low proliferative capacity and death upon culture of activated $\mathrm{CD}^{+}{ }^{+}$cells from HIV-infected individuals $(16,17)$. Indeed, because they form the largest fraction of $\mathrm{T}$ cells, numerically, the majority of cells dying during primary infection were activated $\mathrm{CD} 8{ }^{+} \mathrm{CD} 45 \mathrm{RO}^{+}$cells, but $\mathrm{PCD}$ was observed to the same extent in every $T$ cell subset tested. In three out of four individuals, CD4 expression in apoptotic cells was somewhat decreased, suggesting that $\mathrm{CD}^{+}$cells are dying at higher percentages. However, with small differences, all subsets contained cells dying due to PCD and we did not obtain evidence for preferential death in one specific subset of cells. Our data might indicate that massive immune activation leads to rapid turnover and death of T cells but that PCD affects both cells expressing activation markers as other cells, perhaps as a result of general paucity of growth factors.

In the asymptomatic phase of HIV infection there is a variable but, compared with HIV-negative controls, consistent increase in cells dying due to $\operatorname{PCD}(9,11)$. In agreement with the lesser increase in $\mathrm{CD}^{+} \mathrm{T}$ cell counts, the number of cells in apoptosis in these individuals was never as high as observed in primary infections. Within this small range of $\mathrm{CD}^{+}$cell numbers, no correlation with PCD was found. PCD did not correlate with $\mathrm{CD}^{+} \mathrm{T}$ cell numbers in asymptomatic individuals, nor with $T$ cell function as measured by proliferation to $\mathrm{CD} 3$ $\mathrm{mAb}$ (data not shown), arguing against dramatic changes in the extent of PCD with progression to disease. Longitudinal analysis of four individuals throughout infection also demonstrated a variation but not a consistent increase or decrease in the number of cells in apoptosis over time. No correlation of PCD with virus load or presence of SI and NSI variants could be demonstrated. It is of interest to note that individual RV (Table II) is a long-term asymptomatic individual with stable $\mathrm{CD}^{+} \mathrm{T}$ cell counts, good polyclonal $\mathrm{T}$ cell functions, strong cellular responses against HIV proteins, and a low virus load. The persistently high percentage of both $\mathrm{CD} 4^{+}$and $\mathrm{CD} 8^{+} \mathrm{T}$ cells in apoptosis in this individual argues against a relation of PCD with progression to disease. What might be the mechanism by which $\mathrm{T}$ cells from HIV-infected individuals are primed for PCD? The initially proposed mechanism, suggesting interaction of soluble gp 120 with $\mathrm{CD}^{+}{ }^{+} \mathrm{T}$ cells as an HIV- specific mechanism to prime T cells for PCD, is not likely to be the only explanation $(8)$. First, previous $(9,11)$ and our present work on $\mathrm{T}$ cell subsets demonstrated that both $\mathrm{CD}^{+}$and $\mathrm{CD} 8{ }^{+}$cells, with a preference for $\mathrm{CD} 8^{+}$cells, are dying due to apoptosis, and second, during primary HIV infection, the number of cells dying exceeds by far the percentage of $\mathrm{CD}^{+}$cells present at that time. Direct virus-induced cell lysis (27) must also be excluded as the main cause of PCD. Not only is the frequency of infected cells during asymptomatic infection too low to explain the cell death observed, there seems to be no clear-cut relation between elevated virus load during both acute and asymptomatic infection and increases in PCD.

PCD upon activation of mature lymphocytes in the periphery has been described under several conditions. The $\mathrm{V} \beta$-specific immune response to superantigens results in PCD of responding $\mathrm{T}$ lymphocytes subsequent to an antigen-mediated expansion in vivo (28). Russell et al. (29) demonstrated death of $\mathrm{T}$ cells from TCR transgenic mice upon antigenic stimulation and subsequent TCR engagement by anti-TCR mAb. Wesselborg et al. (30) described that while freshly isolated T cells from healthy individuals are resistant to PCD, the susceptibility of these cells for induced death increases upon activation and culture. In agreement with our observations in both primary and asymptomatic infection, in these experiments no correlation between susceptibility for death and the expression of a specific activation marker could be demonstrated (30).

PCD, both in these systems and in viral infection, might reflect turnover of cells, necessary to control and terminate an effective immune response. The exact mechanism by which in vivo activation leads to cell death remains to be clarified. The apoptosis-related Fas/APO-1 antigen is known to be preferentially expressed on previously activated or memory $\mathrm{T}$ cells (31). Interaction of Fas with its ligand might play a role by the elimination of excessive immune cells. Second, massive immune activation could lead to exhaustion of growth and survival factors and subsequently result in PCD. Our finding that growth factors in vitro could not prevent cells from HIV-infected individuals from dying does not exclude such a mechanism but could be due to the fact that cells from HIV-infected individuals are already irreversibly primed for PCD in vivo.

Recently, antigen-presenting cell (APC) function, regulating either proliferation and cytokine production or cell death of the responding $T$ cell, was proposed as a mechanism to shape a given immune response (32). We have previously argued that APC dysfunction as a result of HIV infection may cause $T$ cell dysfunction (33), which is also based on observations in HIV-infected chimpanzees. Chimpanzees can become persistently infected with HIV without development of clinical symptoms. T cells of HIV-infected chimpanzees have a normal response to stimulation in vitro and the proportion of $\mathrm{T}$ cells dying due to PCD in infected animals does not exceed that in noninfected animals $(11,12)$. Interestingly, HIV does not infect chimpanzee monocytes and only $T$ cell tropic variants are isolated from infected animals $(12,34,35)$. The absence of infected APC in chimpanzees might be the explanation for the fact that enhanced PCD of T cells does not occur (12).

Our data suggest that PCD in acute HIV infection is a reflection of immune activation leading to high turnover of cells, as is observed in acute virus infections in general. High numbers of apoptotic cells in the early stage of infection are followed by moderately increased numbers of cells dying during the asymptomatic phase. In asymptomatic HIV infection, 
PCD reflects a continuous activation leading to priming for death and deletion of responding $\mathrm{T}$ cells. Although $\mathrm{CD} 4^{+}$cells do not make up the majority of cells that are dying, incessant turnover of $\mathrm{CD}^{+}$cells by PCD may contribute to $\mathrm{CD} 4^{+}$cell depletion, especially when renewal of the $\mathrm{CD}^{+} \mathrm{T}$ cell compartment is eventually affected by HIV (8).

\section{Acknowledgments}

We are indebted to our colleagues working in the laboratory of Marijke Roos for excellent technical support, Berend Hooibrink for skilfully operating the FACStar ${ }^{\circledR}$, and Dr. Richard Jonker from TNO (Rijswijk, Netherlands) for advise on the in situ nick translation technique. Drs. Hanneke Schuitemaker and René van Lier are acknowledged for critical reading of the manuscript.

This study was supported by a grant (90-015) from the Dutch Ministry of Public Health and conducted as part of the Amsterdam Cohort Studies on AIDS, a collaboration of the Municipal Health Service, the Human Retrovirus Laboratory at the Academic Medical Center, and the Department of Clinical Viro-Immunology from the Central Laboratory of the Netherlands Red Cross Blood Transfusion Service.

\section{References}

1. Clerici, M., N. Stocks, R. A. Zajac, R. N. Boswell, D. R. Lucey, C. S. Via, and G. M. Shearer. 1989. Detection of three different patterns of $T$ helper cell dysfunction in asymptomatic, human immunodeficiency virus-seropositive patients. J. Clin. Invest. 84:1892-1899.

2. Miedema, F., A. J. C. Petit, F. G. Terpstra, J. K. M. E. Schattenkerk, F. De Wolf, B. J. M. Al, M. Th. L. Roos, J. M. A. Lange, S. A. Danner, J. Goudsmit, and P. Th. A. Schellekens. 1988. Immunological abnormalities in human immunodeficiency virus (HIV)-infected asymptomatic homosexual men. HIV affects the immune system before $\mathrm{CD}^{+} \mathrm{T}$ helper cell depletion occurs. J. Clin. Invest. 82:1908-1914

3. Van Noesel, C. J. M., R. A. Gruters, F. G. Terpstra, P. Th. A. Schellekens, R. A. W. Van Lier, and F. Miedema. 1990. Functional and phenotypic evidence for a selective loss of memory T cells in asymptomatic HIV-infected men. J. Clin. Invest. 86:293-299.

4. Gruters, R. A., F. G. Terpstra, R. De Jong, C. J. M. Van Noesel, R. A. W. Van Lier, and F. Miedema. 1990. Selective loss of T-cell functions in different stages of HIV infection. Eur. J. Immunol. 20:1039-1044.

5. Schellekens, P. Th. A., M. Th. L. Roos, F. De Wolf, J. M. A. Lange, and F. Miedema. 1990. Low T-cell responsiveness to activation via CD3/TCR is a prognostic marker for AIDS in HIV-1 infected men. J. Clin. Immunol. 10:121-127.

6. Schnittman, S. M., M. C. Psallidopoulos, H. C. Lane, L. Thompson, M. Baseler, F. Massari, C. H. Fox, N. P. Salzman, and A. S. Fauci. 1989. The reservoir for HIV-1 in human peripheral blood is a T cell that maintains expression of CD4. Science (Wash. DC). 245:305-308.

7. Schuitemaker, H., M. Koot, N. A. Kootstra, M. W. Dercksen, R. E. Y. De Goede, R. P. Van Steenwijk, J. M. A. Lange, J. K. M. Eeftink Schattenkerk, F. Miedema, and M. Tersmette. 1992. Biological phenotype of human immunodeficiency virus type 1 clones at different stages of infection: progression of disease is associated with a shift from monocytotropic to T-cell-tropic virus populations. $J$. Virol. 66:1354-1360.

8. Ameisen, J. C., and A. Capron. 1991. Cell dysfunction and depletion in AIDS: the programmed cell death hypothesis. Immunol. Today. 12:102-105.

9. Meyaard, L., S. A. Otto, R. R. Jonker, M. J. Mijnster, R. P. M. Keet, and F. Miedema. 1992. Programmed death of T cells in HIV-1 infection. Science (Wash. DC). 257:217-219.

10. Groux, H., G. Torpier, D. Monté, Y. Mouton, A. Capron, and J. C. Ameisen. 1992. Activation-induced death by apoptosis in $\mathrm{CD}^{+} \mathrm{T}$ cells from human immunodeficiency virus-infected asymptomatic individuals. J. Exp. Med. 175:331-340.

11. Gougeon, M., S. Garcia, J. Heeney, R. Tschopp, H. Lecoeur, D. Guetard, V. Rame, R. Dauguet, and L. Montagnier. 1993. Programmed cell death in AIDS-related HIV and SIV infections. AIDS Res. Hum. Retroviruses. 9:553-563.

12. Schuitemaker, H., L. Meyaard, N. A. Kootstra, S. A. Otto, R. Dubbes, M. Tersmette, J. L. Heeney, and F. Miedema. 1993. Lack of T-cell dysfunction and programmed cell death correlates with inability of HIV-1 to infect chimpanzeemonocytes. J. Infect. Dis. 168:1190-1197.

13. Banda, N. K., J. Bernier, D. K. Kurahara, R. Kurrle, N. Haigwood, R-P. Sekaly, and T. Helman Finkel. 1992. Crosslinking CD4 by human immunodeficiency virus gp 120 primes T cells for activation-induced apoptosis. J. Exp. Med. 176:1099-1106.
14. Stites, D. P., A. R. Moss, P. Bacchetti, D. Osmond, T. M. McHugh, Y. J. Wang, S. Hebert, and B. Colfer. 1989. Lymphocyte subset analysis to predict progression to AIDS in a cohort of homosexual men in San Francisco. Clin Immunol. Immunopathol. 52:96-103.

15. Salazar-Gonzalez, J. F., D. J. Moody, J. V. Giorgi, O. Martinez-Maza R. T. Mitsuyasu, and J. L. Fahey. 1985. Reduced ecto-5'-nucleotidase activity and enhanced OKT 10 and HLA-DR expression on CD8 lymphocytes in the acquired immune deficiency syndrome: evidence of CD8 cell immaturity. $J$. Immunol. 135:1778-1785.

16. Pantaleo, G., S. Koenig, M. Baseler, H. Clifford Lane, and A. S. Fauci. 1990. Defective clonogenic potential of $\mathrm{CD8}{ }^{+} \mathrm{T}$ lymphocytes in patients with AIDS. Expansion in vivo of a nonclonogenic $\mathrm{CD} 3{ }^{+} \mathrm{CD}^{+}{ }^{+} \mathrm{DR}^{+} \mathrm{CD} 25$ - $\mathrm{T}$ cell population. J. Immunol. 144:1696-1704.

17. Prince, H. E., and E. R. Jensen. 1991. HIV-related alterations in CD8 cell subsets defined by in vitro survival characteristics. Cell. Immunol. 134:276-286.

18. Razvi, E. S., and R. M. Welsh. 1993. Programmed cell death of T lymphocytes during acute viral infection: a mechanism for virus-induced immune deficiency. J. Virol. 67:5754-5765.

19. Moss, D. J., C. J. Bishop, S. R. Burrows, and J. M. Ryan. 1985. T lymphocytes in infectious mononucleosis. I. T cell death in vitro. Clin. Exp. Immunol. 60:61-69.

20. Uehara, T., T. Miyawaki, K. Ohta, Y. Tamaru, T. Yokoi, S. Nakamura, and $\mathrm{N}$. Taniguchi. 1992. Apoptotic cell death of primed CD45RO ${ }^{+} \mathrm{T}$ lymphocytes in Epstein-Barr virus induced infectious mononucleosis. Blood. 80:452458.

21. Van Lier, R. A. W., J. H. A. Boot, A. J. Verhoeven, E. R. De Groot, M. A. Brouwer, and L. A. Aarden. 1987. Functional studies with anti-CD3 heavy chain isotype switch variant monoclonal antibodies. J. Immunol. 139:2873-2879.

22. Roos, M. Th. L., J. M. A. Lange, R. E. Y. De Goede, R. A. Coutinho, P. Th. A. Schellekens, F. Miedema, and M. Tersmette. 1992. Virus phenotype and immune response in primary human immunodeficiency virus type 1 (HIV1) infection. J. Infect. Dis. 165:427-432.

23. De Wolf, F, J. M. A. Lange, J. T. M. Houweling, R. A. Coutinho, P. Th. A. Schellekens, J. Van der Noordaa, and J. Goudsmit. 1988. Numbers of CD4 ${ }^{+}$ cells and the levels of core antigens of and antibodies to the human immunodeficiency virus as predictors of AIDS among seropositive homosexual men. J. Infect. Dis. 158:615-622.

24. De Jong, R., M. Brouwer, F. Miedema, and R. A. W. Van Lier. 1991. Human $\mathrm{CD} 8^{+} \mathrm{T}$ lymphocytes can be divided into CD45RA ${ }^{+}$and $\mathrm{CD} 45 \mathrm{RO}^{+}$ cells with different requirements for activation and differentiation. J. Immunol. 146:2088-2094.

25. Sellins, K. S., and J. J. Cohen. 1987. Gene induction by gamma-irradiation leads to DNA fragmentation in lymphocytes. J. Immunol. 139:3199-3206.

26. Koot, M., I. P. M. Keet, A. H. V., Vos, R. E. Y. De Goede, M. Th. L. Roos, R. A. Coutinho, F. Miedema, P. Th. A. Schellekens, and M. Tersmette. 1993. Prognostic value of human immunodeficiency virus type 1 biological phenotype for rate of $\mathrm{CD}^{+}{ }^{+}$cell depletion and progression to AIDS. Ann. Int. Med. 118:681688.

27. Terai, C., R. S. Kornbluth, C. D. Pauza, D. D. Richman, and D. A. Carson. 1991. Apoptosis as a mechanism of cell death in cultured T lymphoblasts acutely infected with HIV-1. J. Clin. Invest. 87:1710-1715.

28. Kawabe, Y., and A. Ochi. 1991. Programmed cell death and extrathymic reduction of $\mathrm{V} 8^{+} \mathrm{CD}^{+} \mathrm{T}$ cells in mice tolerant to Staphylococcus aureus enterotoxin B. Nature (Lond.). 349:245-248.

29. Russell, J. H., C. L. White, D. Y. Loh, and P. Meleedy-Rey. 1991. Receptor-stimulated death pathway is opened by antigen in mature T cells. Proc. Natl. Acad. Sci. USA. 88:2151-2155.

30. Wesselborg, S., O. Janssen, and D. Kabelitz. 1993. Induction of activation-driven death (apoptosis) in activated but not resting peripheral blood $\mathrm{T}$ cells. J. Immunol. 150:4338-4345.

31. Miyawaki, T., T. Uehara, R. Nibu, T. Tsuji, A. Yachie, S. Yonehara, and N. Taniguchi. 1992. Differential expression of apoptosis-related Fas antigen on lymphocyte subpopulations in human peripheral blood. J. Immunol. 149:37533758.

32. Wang, R., K. M. Murphy, D. Y. Loh, C. Weaver, and J. H. Russell. 1993. Differential activation of antigen-stimulated suicide and cytokine production pathways in $\mathrm{CD}^{+} \mathrm{T}$ cells is regulated by the antigen presenting cell. J. Immunol. 150:3832-3842.

33. Meyaard, L., H. Schuitemaker, and F. Miedema. 1993. T-cell dysfunction in HIV infection: anergy due to defective antigen presenting cell function? Immunol. Today. 14:161-164.

34. Watanabe, M., D. J. Ringler, P. N. Fultz, J. J. MacKey, J. E. Boyson, C. G. Levine, and N. L. Letvin. 1991. A chimpanzee-passaged human immunodeficiency virus isolate is cytopathic for chimpanzee cells but does not induce disease. J. Virol. 65:3344-3348.

35. Gendelman, H. E., G. D. Ehrlich, L. M. Baca, S. Conley, J. Ribas, D. C. Kalter, M. S. Meltzer, B. J. Poiesz, and P. Nara. 1991. The inability of human immunodeficiency virus to infect chimpanzee monocytes can be overcome by serial viral passage in vivo. J. Virol. 65:3853-3863. 